\title{
LESSON PLAN DEVELOPMENT BASED ON CHARACTER FOR THE TENTH GRADE STUDENTS OF VOCATIONAL SCHOOL
}

\author{
Putra, B.M. \\ Informatics Management, Ganesha Guru Polytechnics \\ Singaraja, Indonesia \\ e-mail: bayoe.mahaputra@gmail.com
}

\begin{abstract}
This study was a Research and Development study (R\&D) used Sugiyono's model which aimed at (1) analyzing the design of the existing English lesson plans in SMK Triatma Jaya Singaraja, (2) identifying the problems faced by the English teacher in designing good English lesson plans (3) determining the good design of Character Based English Lesson Plans in SMK Triatma Jaya Singaraja (4) determining the quality of the Character Based Lesson Plans developed. The data of the present study were analyzed descriptively and quantitatively. This result showed that the existing lesson plans did not clearly state the values of nation character and the assessment and it was not explicitly stated on the learning activity. The learning activity seemed monotone. There seemed to be materials repetition. The materials must be suitable with the students' department. The lesson plans developed were designed based on technical guideline of lesson plan development proposed by Board Directors of Senior High School Development (2010) with character assessment as an addition. The lesson plans were developed in form of integrated lesson plan. The lesson plans developed were effective and the quality is excellent.
\end{abstract}

Keywords: lesson plan, the values of nation character

\section{INTRODUCTION}

Education is defined as a conscious planned action to create learning atmosphere and learning process in which the students develop their potency actively to get religious spiritual competence, self control, character, intelligence, fine moral, and skill needed by themselves, society, country and the nation (Act 20 2003). Ideally if the education process is conducted properly, the quality of human resources and society will develop significantly into promising positive perspective.

However, the social cultural situation of society is referring to the negative direction. There are miserable phenomena of education which harassing the human itself. Many embarrassing cases blown up such as the degradation of moral values, unfairness action, degradation of solidarity, juvenile delinquency and the rapid development of corruption even within the education system itself.

This condition should be reduced by providing character education. Especially for Indonesia, since 2003 the character education has been started. It is the education reform aimed at developing the values of the nation character so that students will well behave. The implementation of education character is not in separate subject. It is incorporated in every subject. Meaning that, character education is not done explicitly rather developed trough the teaching of other subjects, such as math, science, and English.

Especially for English, the incorporation of character education is highly required. It is because language learning has central role in students' intellectual, social, and emotional development and becomes key element of success in learning other disciplines. Language learning is expected to help learners to understand themselves, their culture and the others culture.

More importantly for SMK which major in tourism, English should be inserted with character education. By inserting the character education, students will be able to develop their good conduct. Moreover, character education will help students to identify their aptitude and interest, obstacle in work field, and ability to provide strategy to solve problem in work field. So that students will then become competent workers.

Character education is started in 2 phases. They are theoretical phase and practical phase. Theoretical phase is started by listing the values on the school syllabus. It is not yet ready to use. The 
practical phase of the character education will be in the form of lesson plan. It is the implementation of character education in the classroom, guided by the use of lesson plan.

However, character based lesson plan is not available at SMK Pariwisata Triatma Jaya Singaraja. The Lesson plan used is the ordinary one, without the implementation of character education. It is not suitable with the spirit of character education. On the lesson plan used, there was no implicit activity for character education. Therefore, considering the problem faced, there was an urgent need to develop lesson plan which include the development of the values of nation character.

The development of the lesson plans was done trough $\mathrm{R} \& \mathrm{D}$ research. The present research is aimed at: (1) identifying the problems identified in the existing Lesson Plans used by English teacher at SMK Triatma Jaya Singaraja, (2) identifying the needs of the Lesson plan for teaching English at SMK Triatma Jaya Singaraja, (3) determining the suitable design of Character Based Lesson Plan for teaching English at SMK Triatma Jaya Singaraja, (4) developing Character Based Lesson Plan for teaching English at SMK Triatma Jaya Singaraja, (5) determining the quality of the Lesson Plan developed, and (6) measuring the effectiveness of the lesson plan developed.

\section{Curriculum}

Curriculum is an indispensabe part of any formal education, and plays vital part in it. The term curriculum, however, means different things to different people, the followings are some opinions regarding the term curriculum. The National Education Standardization Board (BSNP) defines curriculum as a set of plans and arrangements about aim, contents, and subject matter material and the technique of implementation, which is used as a guideline of education implementation to achieve certain educational goals (BSNP, 2006).

Kwartolo (2002) as cited in Meiyana (2010) defines curriculum as a plan or program for all of the experiences which the learner encounters under the direction of the school (organization or institution). In practice, the curriculum consists of a number of plans, in a written form and of varying scope, which delineate the desired learning experiences. The curriculum, therefore, may be a unit, a course, a sequence of courses, and the school's (organization or institution) entire program of studies and may take place outside of the classroom or school.

In line with the above definitions, the Indonesian National Education System Act No. 20 year 2003 defined curriculum as a set of arrangements and settings about objectives, content, and learning material, and the means which is used as the guidelines of implementing learning activities in achieving certain objectives.

From the definitions of curriculum above, we can further recognize that curriculum is a central education planning which involves the participant of all school components comprising decision makers, educators, students, educational experts, and societies including school committee; stake holder; entrepreneurs; and government. Curriculum contains learning materials and sources organized systematically regarding the levels of students' achievement and their degrees. A curriculum may also refer to a defined and prescribed course of studies, which students must fulfill in order to pass a certain level of education. For example, an elementary school might discuss how its curriculum, or its entire sum of lessons and teachings, is designed to improve national testing scores or help students learn the basics. An individual teacher might also refer to his or her curriculum, meaning all the subjects that will be taught during a school year.

Curriculum started with the objectives as the aim which must be achieved. The objectives will determine the learning materials used, and the learning materials used will determine the kind of teaching learning activities conducted which finally will result in a certain form of assessment. However, one thing must keep in mind that the development and events happening in the assessment may cause changes to the teaching learning activities, which may also lead to changes in learning materials and so on. Therefore a curriculum may undergo changes as it is implemented as a result of problems, obstacles and deficiency found within the implementation.

\section{Syllabus}

Syllabus is a planning of teaching learning in a and/or group of subject/theme which includes competence standard, basic competence, learning indicator, learning objective, learning material, time allocation, teaching method, teaching learning activities, teaching evaluation, and learning source (Arrangement Guidance of School Based Curriculum published by Educational National Standard Agency, Chapter III, Item A) The syllabus serves many purposes for the students and the teacher such as ensuring a fair and impartial understanding between the instructor and students such that there is 
minimal confusion on policies relating to the course, setting clear expectations of material to be learned, behavior in the classroom, and effort on student's behalf to be put into the course, providing a roadmap of course organization/direction relaying the instructor's teaching philosophy to the students, and providing a marketing angle of the course such that students may choose early in the course whether the subject material is attractive.

Moreover, syllabus is a document that a teacher writes and distributes to provide students with an overview of a course. It is usually distributed on the first day class. It contains several parts, namely the course title and the meeting times, the name of the teacher and his / her contact information, expectations and attendance policies, topics and chapters covered, test dates, other relevant dates, grading policy and required texts and other supplies. It can be said as our key to success. It is because a syllabus has important role as a time management tool and put every important date in our planner right away. The aim of syllabus development is to enable teachers to elaborate the basic competence from the standard content and state indicators of the basic competence, to map the materials into appropriate scope and sequence of materials, to elaborate the evaluation into types and kinds of evaluation, and learning process into learning experiences (Muhaimin, et al. 2008, 112-113)

\section{Lesson Plan}

Lesson plan is a plan to picture procedure and organization of teaching to achieve a basic competence (material of School Based Curriculum Technical Guidance 2009). Lesson plan is described from syllabus to direct students' learning activities in achieving basic competence (Attachment of Regulation of National Education Minister No 41 2007, II Item B). Lesson plan contains subject matter, competence standard, basic competence, learning indicator, learning objective, learning material, time allocation, teaching method, teaching learning activities, teaching evaluation, and learning source.

\section{METHODS}

This present study is research and development. The model of the development is the one proposed by Sugiyono. However due to time limitation, the Sugiyono model was simplified. The steps involved in this study were; Problems Identification, Data Collection, Product Design, Design Validation, Design Revision, Product Testing, Product Revision and Final Product.

Problems Identification was done through the process of document analysis. The documents analyzed were English syllabus and existing lesson plan. The data was collected trough conducting library research, and interview. The data were used in product design process. The design of the product was done through the process of document analysis. It was based on the data collected previously. The product must be able to cover the problem found and match with the theoretical requirement of a lesson plan. Design Validation was a process of validating the product theoretically by the assistance of expert judgments. This process was done trough document analysis. Judges determined whether or not the lesson plan meets the theoretical requirement of a lesson plan by looking at the product and rubric. It was important to ensure the quality of the product developed in term of theoretical ground. Design Revision process was done trough document analysis. The documents were the comment from the Judges. The researcher revised the design based on the comments given by the judges. Product Testing was done trough the series of tests. The tests were pre-test and post-test. The result of the pre-test and post-test were then compared to determine how effective the lesson plan was. Product Revision was done trough document analysis. The document was the comment given by teacher. Final Product is the product which is ready to release.

This study was conducted in SMK Pariwisata Triatma Jaya Singaraja. The subjects of this study were the tenth year students and English teacher of Vocational School of SMK Triatma Jaya Singaraja in the academic year 2013/2014. The object of the study was Character-Based Lesson Plan.

The processes of collecting the data in this study were conducted through: (1) document analysis, (2) interview, (3) rubric, (4) questioner, and (5) test. The instruments for collecting data were (1) interview guide, (2) document analysis worksheet, (3) questionnaire, (4) rubric, and (5) test. 


\section{RESULT AND DISSCUSSION}

\section{The Design of the Existing Lesson Plan Used by the English Teacher in SMK Triatma Jaya Singaraja}

Lesson plan plays an important role as a guideline in teaching and learning process. It manages how the procedure of teaching and learning process will be, what method is used, how the material limitation is, and it also states how to assess such kind of activities. Therefore, lesson plan is a clear teaching referent to manage the class.

In order to answer the problem statement number one, it was a need to observe the existing lesson plan of the teacher in SMK Triatma Jaya.

\section{Subject Identity}

By analyzing the existing lesson plan used in SMK Triatma Jaya, it could be described that this lesson plan have stated some basic component that are commonly used in lesson plan, such as; school, course, class and specific department, semester, teaching material, and time allocation although it did not clearly state in what meeting the material should be taught. It caused disordered lesson plan while the teacher plans to teach a certain material whether at the third or fourth meeting. Then, the teaching material stated in the existing lesson plan was a bit confusing since it stated listening, reading, writing, and speaking as teaching material itself. It was confusing because the part of teaching material in lesson plan should state a clear description of material itself and not about the skill that will be the activity during teaching and learning process. Learning material contained fact, concept, principle, and relevant procedure written in form of items according to the formula or learning objective (regulation of National Edication Minister No 412007 about process standard). Thus, learning material should not be stated in the beginning of the lesson plan, since it appeared after stating the objective of the study. Thus, at the beginning of the lesson plan, it should just state a topic. Then, the part of teaching material describes detail material description of the topic.

\section{Standard Competence and Basic Competence}

The standards competence and basic competence have also stated in the lesson plan. It was taken based on the syllabus itself. The standard competence in the existing lesson plan stated that the level of English taught in vocational school is novice level. It also proved in basic competence, which states about describing thing around oneself. It indicates that, in the first grade of vocational school, teaching English is focused on novice level.

\section{Indicator and Learning Objective}

The indicators in the existing lesson plan have showed correlation with the learning objective. The indicator was formulated by using operational verb which can be measured and observed, that included knowledge, attitude, and skill (Regulation of National Education Minister No 412007 about process standard). Then, learning objective describes process and output of the learning to be achieved by students based on the basic competence (Regulation of National Education Minister No 412007 about process standard). Learning objective can include several indicators, or a learning objective for several indicators. The most important is that learning objective should refer to the indicator achievement (presentation material of school based curriculum technical guidance 2009).

\section{Learning Materials}

The learning material in the existing lesson plan showed many kinds of daily conversation used for daily life regarding to the material. The material in the beginning semester of vocational school introduces how to introduce self and other in formal and informal way. It showed also the responds of those expressions. In the example of the conversation above, it was stated the daily conversation between friends; introducing self, and add some point of thanking and greeting. Several learning material in the existing lesson plans has contained relevant procedure with the learning objective. There have been a correlation between what the learning objective want to achieve and how the order of learning material. However, a criteria of learning material for Vocational school by BSNP is missing. BSNP (2007) about criteria of learning material for SMK stated that, Learning material should technology and knowledge development.

\section{Learning Method}

In the existing lesson plan, there is only one learning method used. Role play in almost used in whole leaning method in the existing lesson plan. In a role play, the students play a part they do not play in real life. In a role play, participants assign roles which they act out within scenario. One way, 
or the other, role play prepares L2 learners for L2 communication in a different social and cultural context (Kodotchigova, 2002).

\section{Learning Activity}

In the existing lesson plan, the activities includes pre-activities, whilst activities, and post activities. In the whilst activities, the activities were divided into three activities; exploration, collaboration, and confirmation. These three activities help the teacher to manage the students' activities during leaning activities in order to achieve the learning indicators.

\section{Learning Sources}

Learning sources in the existing lesson plan used vocabularies related to the material given. However, it did not clearly state the teaching media used in learning activities. Then, as the learning sources, the teacher used a book from national education department, English for SMK. This book contained of some material related to the syllabus, thus, the teacher chooses this book as learning resources.

\section{The Assessment}

The assessment of the existing lesson plan was divided into three; assessment technique, kind of instrument, assessment instrument. As assessment technique, it used performance assessment. Then, in the assessment instrument, it used a rubric based on what was assessed to the students.

\section{The Problems Faced by the Teacher in Designing a Good Lesson Plan}

In finding the problems, the researcher conducted two methods; questionnaire and interview. The questioner was made based on the technical guideline of lesson plan development proposed by Board Directors of Senior High School Development (2010) for KTSP (school based curriculum). The result showed that the teacher faced difficulties in designing various materials. It can be proved from the material in the existing lesson plan, where the repetitions existed. Teacher used the same materials for her lesson plan. By the interview conducted to the teacher, the teacher said that, it caused by the difficulties in finding the sources to find authentic material for leaning activities. As consequences, the teacher tended to use monotone material that is inappropriate with the students' needs.

Then, the teachers' problem was also found in designing learning activities. The learning activity missed the aspects of apperception and elaboration, where actually by defining those activities, the learning activities could be reflected in detail. In the lesson plan, the apperception was not written on the lesson plan. So, it could not be seen the activity conducted by the teacher to connect the real life condition and the classroom learning.

Regarding to learning activities, the teacher also faced difficulty in designing various activities for teaching. Teacher used the same activity in her lesson plan, even for different discussion. It caused by the teacher, who tended to use role play as assessment in almost whole lesson plan. Thus, the activities in the lesson plan seemed to be monotone.

The teacher also faced some difficulties of all about nation character such as the assessment of the development value of nation character. From the interview conducted, the teacher missed the things about character value caused by the limitation of explanation from the expertise of how to determine and apply it in the lesson plan. Thus, in the existing lesson plan, it was not provided yet.

Regarding to the limitation explanation of determining national character in the lesson plan, the lesson plan also did not clearly state which value of nation character to develop. The values which need to be developed were not written on the lesson plan. Therefore, it could not be seen what values are being developed.

\section{The Design Character Based Lesson Plan for Tenth Grade of Vocational School}

The design to develop the lesson plan was conducted through the following process:

Problem Identification.

The first process of the development was conducted to find out the problem of the existing lesson plan. The problems were identified through conducting the document analysis. The basis for deciding the problem was the existence of the value of the nation character and the guideline for developing lesson plan issued by Board Directors of Senior High School Development (2010) for KTSP (school based curriculum). The problems identification is vital here as it can direct the development of the lesson plan. The new lesson plan, at least, must be able to cover the problem of the existing lesson plan. If not, the development is useless.

Data Collection. 
The data obtained here are the need of the syllabus, teacher and students. For the first semester syllabus of SMK Triatma Jaya Singaraja, there are four basic competences in which they comes under the same competence standard.

Product Design.

The structure of the lesson plan was based on the technical guideline of lesson plan development proposed by Board Directors of Senior High School Development (2010) for KTSP (school based curriculum). This guideline proposed complete structure of the lesson plan. However, the assessment of the values of the lesson plan is experiencing modification. The assessment used in the developed lesson plan is more comprehensive than before. It contains more detailed indicators for each of the value being assessed, the assessment on the guideline only contain rubric without any clear indicators. In short it can be said that, the structure is derived from the technical guideline of lesson plan development proposed by Board Directors of Senior High School Development (2010) for KTSP (school based curriculum) with additional point on the assessment of the values of the nation character. The content was based on the need of the syllabus, teacher, and student. It was actually the implementation of the school based curriculum which emphasized on the school resources. Therefore, the developed lesson plans were different from the ones used in other schools in term of its contents.

\section{The Quality of Character Based Lesson Plan Developed in SMK Triatma Jaya Singaraja}

Expert judgment was done while the product was under development. The result shows that the product has very high validity. It means that lesson plans are valid in term of their content and construct.

In relation to the present research, the expert comment on how the lesson plan should be organized. On the initial development, the researcher developed the lesson plans based on the language skills. It means that lesson plans are divided into speaking, listening, reading and writing but the materials are still the same for every skill. The experts wanted to change this by materials based lesson which integrates all the language skills in it. This will provide opportunity to have authentic language use in a meaningful situation.

The data to determine the effectiveness of the lesson plans in term of how well the lesson plan improves students' competence was collected trough conducting pre-test and post-test. The pre-test and post-test were included in the lesson plan as part of the assessment. The data from pre-test and post-test are then compared, the difference between the result of the pre-test and post test is the basis for determining the effectiveness of the lesson plans.

The data to determine the effectiveness of the lesson plans in term of how well they can develop the value of character among students was seen on the result of the observation. The result of the observation was then tabulated to find the score of each item in the observation sheet.

\section{The Result of Pre-test and Post-test}

The average scores of XAP1 increased. Before the implementation, the average mean score was 75. After the implementation it increased to 77. It was also happened to XAP2. Before implementing the developed lesson plan, the average scores for three lesson plan was 69.6. After implementing three of developed lesson plan, the average scores raised to 74.2. XAP3 and XAP4 also experienced similar changes with their average scores. The average of their pretest scores rose from 77.4 and 74.2 to 82.3 and 78.3. All those scores increased in different range. It happened because different class got different group of lesson plan with different materials. It was obvious that different materials had different level of complexity. The class also consisted with various characteristics of students. Therefore, those differences produced different result in pretest and posttest. The result of fourteen developed lesson plans indicated that the developed lesson plans were accepted. Students accepted the materials, the methods and strategies, and the test by showing the positive results. In this case, the positive result was their improvement in scores' test. Figure 1 shows that the average result of the test was increasing. 


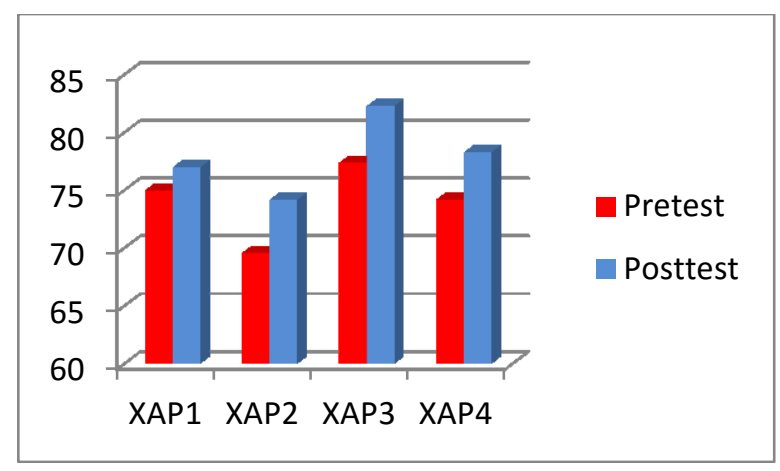

Figure 1. The result of Pre-Test and Post-test

\section{The Result of Assessment for Character Education}

The Result of Assessment in XAP1

In the process of implementing developed lesson plan, there were several findings obtained. In the beginning of implementation, the teacher always asks the students to pray. Some students did not take it seriously. They disturbed others. After implementing four developed lesson plan to XAP1, their religious character was developed. They started to pray seriously and did not disturb their friends. During the teaching process, there were two students who did not obey the teacher's instruction. For example, when the teacher asked to prepare themselves before learning, they did not obey the instruction. They also did not show their best. They did not work hard in doing the task. It happened until the fourth implementation. In relation to curiosity, creative and democratic, nearly $80 \%$ of students did not demonstrate these characters until the fourth implementation. Obviously, the students in XAP1 needed more activities to push their curiosity, creativity and democratic character. In addition, there were also two students needed more attention.

The Result of Assessment in XAP2

In XAP2 class, there were three of developed lesson plans implemented. In general, those three developed lesson plans gave positive result in developing religious, discipline and hard work character. In the last implementation, the students started to pray seriously and did not disturb others. They also followed the teacher's instruction and paid attention to others performance. In completing the teacher's task, they showed their best and worked hard. However, the developed lesson plan failed to build up their curiosity, creativity and democratic character. Until the third implementation, the students could not demonstrate those three characters. They did not demonstrate action to know deeper about the teacher explanation. They were not creative and only copied the teacher's example. In expressing their opinion, they were still shy. They felt hesitate to speak loudly and clearly. They were still not confidence with themselves. This class needed more implementation and more attention. For the lesson plan, it needed more development in its activities.

The Result of Assessment in XAP3

The implementation of developed lesson plans in XAP3 class also showed progress. There were four lesson plan implemented in this class namely; lesson plan number seven, eight, nine and ten. They were 32 students as participants. Until the last implementation, there was one student who gave negative feedback toward the activities in the lesson plan. He did not demonstrate his curiosity toward the lesson. He was indiscipline and not creative. He just copied others work. Moreover, he could not express his ideas clearly and could not demonstrate his best effort to complete the task. The rest of the students showed positive result. Even their character did not match with the indicators at the first meeting; they developed their characters in the next meetings. They prayed seriously before start learning. They followed the teacher's instruction and worked hard in completing the task. Their creativity and curiosity were developed during the lesson. Most of them also started to speak their ideas to the class. It can be seen that even there was students failed to develop his characters, all four implementation of developed lesson plan gave chances to the rest of students to build up their characters. 


\section{The Result of Assessment in XAP4}

From the fourteen of developed lesson plan, XAP4 class got the last four of lesson plan. There were 32 students in this class. During the implementation of the developed lesson plan, 30 students gave positive respond toward the activities in the lesson plan. They developed the religious character by demonstrate a serious praying and did not disturbed others. They were also discipline in following the lesson. The students obeyed the teacher's instruction. They also tried to show their best in working the task. Those 30 students had tried to get deeper understanding toward the lesson, to make something different and to express their opinion to others. However, until the last implementation, the other 2 students still did not show their character development. They did not demonstrate all indicators. In summary, there was no major problems existed during the implementation in XAP4 except those two students who needed more guidance.

\section{CONCLUSION}

Based on the research questions, the objective of the study, data finding, and discussion of the study mentioned previously, it can be concluded that by analyzing the existing lesson plan used in SMK Triatma Jaya, it could be described that this lesson plan have stated some basic component that are commonly used in lesson plan, such as; school, course, class and specific department, semester, teaching material, and time allocation although it did not clearly state in what meeting the material should be taught. Then, the teaching material stated in the existing lesson plan was a bit confusing since it stated listening, reading, writing, and speaking as teaching material itself. Learning material should not be stated in the beginning of the lesson plan, since it appeared after stating the objective of the study. The standards competence and basic competence have also stated in the lesson plan. The indicators in the existing lesson plan have showed correlation with the learning objective. The learning material showed many kinds of daily conversation used for daily life regarding to the material. In the existing lesson plan, there is only one learning method used. Role plays in almost used in whole leaning method in the existing lesson plan. The activities includes pre-activities, whilst activities, and post activities. Learning sources in the existing lesson plan used vocabularies related to the material given. However, it did not clearly state the teaching media used in learning activities. The assessment of the existing lesson plan was divided into three; assessment technique, kind of instrument, assessment instrument. As assessment technique, it used performance assessment. Then, in the assessment instrument, it used a rubric based on what was assessed to the students.

Moreover, in finding the problems, the researcher conducted two methods; questionnaire and interview. The questioner was made based on the technical guideline of lesson plan development proposed by Board Directors of Senior High School Development (2010) for KTSP (school based curriculum). The result showed that the teacher faced difficulties in designing various materials. It can be proved from the material in the existing lesson plan, where the repetitions existed. Then, the teachers' problem was also found in designing learning activities. The learning activity missed the aspects of apperception and elaboration, where actually by defining those activities, the learning activities could be reflected in detail. Regarding to learning activities, the teacher also faced difficulty in designing various activities for teaching. Teacher used the same activity in her lesson plan, even for different discussion. The teacher also faced some difficulties of all about nation character such as the assessment of the development value of nation character. Regarding to the limitation explanation of determining national character in the lesson plan, the lesson plan also did not clearly state which value of nation character to develop.

The design to develop the lesson plan was conducted through problem identification, data collection product design,. Problem Identification as the first process of the development was conducted to find out the problem of the existing lesson plan. The data obtained here are the need of the syllabus, teacher and students. For the first semester syllabus of SMK Triatma Jaya Singaraja, there are four basic competences in which they comes under the same competence standard.

The structure is derived from the technical guideline of lesson plan development proposed by Board Directors of Senior High School Development (2010) for KTSP (school based curriculum) with additional point on the assessment of the values of the nation character. The content was based on the need of the syllabus, teacher, and student. It was actually the implementation of the school based curriculum which emphasized on the school resources. Therefore, the developed lesson plans were different from the ones used in other schools in term of its contents. The lesson plans developed are 
excellent based on the evaluation of the expert judgment. The lesson plans are also effective. It means that the lesson plans developed can improve students' competence and can develop the values of nation character among students.

\section{REFERENCES}

. 2010. Juknis Pengembangan RPP SMA. Retrieved from http://teguhsasmitosdp1.files.wordpress.com/2010/06/21-juknis-pengembangan-rpp- isirevisi_0104.pdf on 23th August 2013

Peraturan Menteri Pendidikan Nasional (Permendiknas) Nomor 41 Tahun 2007

Undang-Undang Republik Indonesia nomor 20 tahun 2003 tentang Sistem Pendidikan Nasional (UU Sisdiknas)

Azwar, Saifuddin. 2001. Tes Prestasi: Fungsi dan Pengembangan Pengukuran Prestasi Belajar. Yogyakarta: Pustaka Pelajar.

Susanti, Meyana Aris I Luh. 2012. Developing Reading Materials for the Eighth Year Students of Junior High School at SMP Negeri 2 Singaraja (thesis). Singaraja: Undiksha Singaraja.

Gall. Meredith D. \& Gall. Joyce P. 2003. Educational Research. New Jersey: Pearson Education, inc

Muhaimin. 2008. Pengembangan Model KTSP Pada Sekolah dan Madrasah. Jakarta. PT. Rajagrafindo Persada.

Nurgiantoro, Burhan. 2010. Penilaian Pembelajaran Bahasa Berbasis Kompetensi. Yogyakarta: BFPE-Yogyakarta.

Saputra, K.A.O. 2013. Developing Character-Based Assessment in Teaching English for the Tenth Grade Students of SMKN 3 Singaraja Thesis. Singaraja: Language Education Department, Postgraduate Program Ganesha Education University, 2013

Susanti, Meyana Aris I Luh. 2012. Developing Reading Materials for the Eighth Year Students of Junior High School at SMP Negeri 2 Singaraja (thesis). Singaraja: Undiksha Singaraja.

Sugiyono. 2010. Metoda Penelitian Kuantitatif, Kualitatif, dan R\&D. Bnadung: Alfabeta Bandung 